\title{
Overview of Comprehensive Information Quality Management under Mass Customization
}

\author{
Ren Mengmeng* \\ Nanjing Tech University \\ NJ 210009, China
}

Fan Shuhai

Nanjing Tech University

NJ 210009, China

MIT Quality Information Program “Data Quality \& Info

Security” Lab, Cambridge, MA, USA

\author{
Zhao Lingling \\ Nanjing Tech University \\ NJ 210009, China \\ 864695857@qq.com
}

\author{
Lv Qingwen \\ Nanjing Tech University \\ NJ 210009, China
}

\author{
Xu Wenhao \\ Nanjing Tech University \\ NJ 210009, China
}

\begin{abstract}
Mass customization is a mode of production for a single customer or a large number or varieties of products in the market. It is based on the mass production of the cost and speed. But due to the presence of the customer diversification and personalized order, make mass customization information quality management more complex and difficult. This paper outlines the necessity of information management under mass customization, and puts forward the concept, basic theory and recursive formula of the total information quality management.
\end{abstract}

Keywords-Mass Customization, The Total Information Quality Management, The recurrence formula

\section{INTRODUCTION}

With the continuous development of diversified markets, Mass Customization has not satisfied the original mass customization, and the demand for personalized customers also has greatly increased the difficulty of mass customization. This has made the original information quality management model extremely challenging. This has made the original information management model suffer extremely challenging. First of all, China's mass customization started late, and many companies have not yet established a CRM system, resulting in a long-term lack of customer data; Secondly, the ever-changing market has led to a shortened information demand cycle for mass customization, and the information update speed far exceeds the original information reserve; Finally, it is difficult for Chinese enterprises to effectively play the role of mass customization under the constantly changing and dynamic market changes. The piecemeal experience cannot adapt to the current level of productivity.

Based on the current large-scale customization of current data, poor information, and broken experience, this paper summarizes the experience of predecessors and summarizes the concept and basic theory of the total information quality management. And according to the comprehensive information quality management, a recurrence formula is proposed to solve the main problems of mass customization in China.

\section{BASIC THEORY}

\section{A. Mass Customization}

The idea of mass customization was first proposed by Alvin Toffler in $1970{ }^{[1]}$.In 1993, B Joseph Pine II officially proposed the concept of mass customization for the first time: providing customized personalized products and services at the cost and time of mass production ${ }^{[2]}$.After later, Jiao $\mathrm{J}$ X ${ }^{[3]}$, Hart C W ${ }^{[4]}$, et al. also proposed concepts. Chinese scholars Shao Xiaofeng ${ }^{[5]}$, Zhang Ping ${ }^{[6]}$ also made further research. Professor Qi Guo-ning ${ }^{[7]}$ of Chinese scholars believes that, mass customization is a kind of "under the guidance of system thinking, using the overall optimization point of view, making full use of the various resources available to enterprises, in standard technology, modern design methods, information technology, and the support of advanced manufacturing technology, according to the individual needs of customers, the production methods of customized products and services are provided at low cost, high quality and high efficiency in mass production." The core of mass customization is to convert all or part of the product's custom production problems into mass production, and to customize any number of products for individual customers or small batch multi-variety markets with the cost and speed of large-scale production ${ }^{[8]}$.

\section{B. Quality Control}

Quality is the key to satisfying customer needs in the mass customization production. Juran once said: The future 21st century will be "the century of quality". He believes that quality is "applicability". Feigenbaum argues that quality is "an integrated product and service characteristics that satisfies customer expectations through products and services in all markets, engineering, manufacturing and maintenance". P.B.Crosby believes that "quality is in line with the requirements." In addition, the world-famous quality masters Kaoru Ishikawa ${ }^{[9]}$, Deming ${ }^{[10]}$, and Genichi Taguchi ${ }^{[11]}$ have all explained the definition of quality. However, on a global scale, the specific quality standard currently implemented is ISO9000:2000, in which quality is defined as the degree to which a set of inherent characteristic meets the requirements $^{[12]}$.

At present, there is no uniform definition of quality management. In a way, scholars at home and abroad have 
different requirements on quality management. Table 1 briefly summarizes the theories, advantages and limitations of several quality management scholars at home and abroad.

Quality management under mass customization is generally manifested as customer satisfaction, design quality and information quality management in the manufacturing process. And quality management runs through the whole process of mass customization.

TABLE I. COMPARISON OF QUALITY MANAGEMENT SCHOLARS’ THEORY AND ADVANTAGES AND DISADVANTAGES

\begin{tabular}{|c|c|c|c|}
\hline scholar & theory & advantage & limitation \\
\hline Juran & Juran Ttrilogy & universal & Basics \\
\hline $\begin{array}{l}\text { Kaoru } \\
\text { Ishikawa }\end{array}$ & PDCA & $\begin{array}{l}\text { Objectify } \\
\text { Standardization }\end{array}$ & $\begin{array}{l}\text { not include } \\
\text { human } \\
\text { creativity. }\end{array}$ \\
\hline Feigenbaum & $\begin{array}{l}\text { Quality Control } \\
\text { Circle } \\
\text { (QCC) }\end{array}$ & $\begin{array}{l}\text { Bottom-up } \\
\text { Step by step }\end{array}$ & $\begin{array}{l}\text { Strong } \\
\text { geographical } \\
\text { limitations } \\
\text { Manpower } \\
\text { required }\end{array}$ \\
\hline P.B. Crosby & $\begin{array}{l}\text { Total quality } \\
\text { management } \\
(\mathrm{TQM})\end{array}$ & $\begin{array}{l}\text { From top to } \\
\text { bottom } \\
\text { Strong } \\
\text { professionalism }\end{array}$ & $\begin{array}{l}\text { Poor initiative } \\
\text { Long cycle }\end{array}$ \\
\hline $\begin{array}{l}\text { Genichi } \\
\text { Taguchi }\end{array}$ & Zero Defect & $\begin{array}{l}\text { Strong initiative } \\
\text { Request } \\
\text { quantification }\end{array}$ & $\begin{array}{l}\text { Ignore customer } \\
\text { needs }\end{array}$ \\
\hline $\begin{array}{l}\text { Zhang } \\
\text { Gong-xu }\end{array}$ & $\begin{array}{l}\text { Quality Loss } \\
\text { Function }\end{array}$ & $\begin{array}{l}\text { Quantitative } \\
\text { quality } \\
\text { Management } \\
\text { and loss }\end{array}$ & $\begin{array}{l}\text { Based on } \\
\text { Deming and } \\
\text { P.B. Crosby }\end{array}$ \\
\hline $\begin{array}{l}\text { Kaoru } \\
\text { Ishikawa }\end{array}$ & $\begin{array}{l}\text { The two kinds } \\
\text { of quality } \\
\text { Multivariate } \\
\text { diagnosis }\end{array}$ & $\begin{array}{l}\text { Multi-process } \\
\text { production } \\
\text { highly targeted }\end{array}$ & Not universal \\
\hline
\end{tabular}

\section{Information Quality Management}

The quality of information not only represents the usefulness of information, but also determines the degree of product completion and user satisfaction in production. High-quality information comes not only from information system design, information analysis and information resource management, but also from correct understanding of information quality, judgment of information value and effective control and guarantee of information transmission process $^{[13]}$.

In 1991, Richard Y. Wang opened a comprehensive data quality management course at MIT Sloan College, which laid the foundation for theoretical research on information quality. Over the past 20 years, information quality management tools have become increasingly mature, product defect defense capabilities have also been increased, and information quality research has never been interrupted. Figure 1 shows the number of CNKI journals on the subject of information quality management in the past decade.

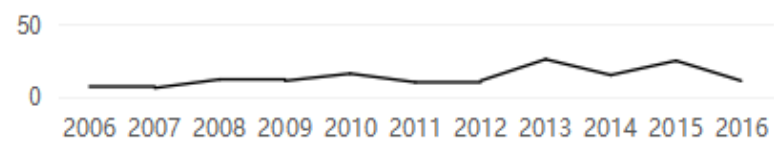

$$
\text { Number }
$$

Fig. 1. Number of journals on information quality management in CNKI

\section{THE TOTAL INFORMATION QUALITY MANAGEMENT}

Based on the previous studies on information quality management and TQM, this paper proposes the concept of the total information quality management, including the hierarchical relationship of the total information quality management. This paper holds that total information quality management (TQM) is an activity that aims at satisfying the requirements of information users and guarantees the integrity and accuracy of information by developing information quality, maintaining information quality, improving information quality and guaranteeing information quality. The comprehensiveness of comprehensive information quality management means that the entire process of the management system must participate in management. It is the management of four aspects: symbol, data, information and knowledge, including the whole process of information from the beginning to the contact. Total information quality management (TQM) is based on the exploration of information quality management, and It is also summarized from the definition of symbol, data, information and knowledge in the four stages of information expression and its quality significance.

At present, there is no accurate answer to the definition and relationship between symbols, data, information, knowledge. Table 2 summarizes the research and summary of scholars at home and abroad. In general, information is symbol and data, so data is the specific form of information, information is the logical meaning of data, and knowledge is the information that becomes objective laws. It can be considered that there is a hierarchical relationship between the four.

TABLE II. DEFINITION AND RELATIONSHIP OF SYMBOL, DATA AND INFORMATION KNOW

\begin{tabular}{|c|c|c|c|}
\hline & Definition 1 & Definition 2 & Relations \\
\hline Symbolic & $\begin{array}{l}\text { Symbols are } \\
\text { perceptions } \\
\text { that are } \\
\text { considered to } \\
\text { carry } \\
\text { meaning }{ }^{[16]}\end{array}$ & $\begin{array}{l}\text { It is everything } \\
\text { that conveys the } \\
\text { exact concept of a } \\
\text { thing in some way } \\
\text { [14-15] }\end{array}$ & $\begin{array}{l}\text { The original } \\
\text { message does } \\
\text { not mean } \\
\text { anything until } \\
\text { it is } \\
\text { unprocessed. }\end{array}$ \\
\hline Data & $\begin{array}{l}\text { Data are often } \\
\text { seen as simple } \\
\text { facts }^{[17]}\end{array}$ & $\begin{array}{l}\text { It is the result of } \\
\text { observation, the } \\
\text { logical induction } \\
\text { of objective } \\
\text { things, the raw } \\
\text { material used to } \\
\text { express objective } \\
\text { things }{ }^{[18]}\end{array}$ & $\begin{array}{l}\text { Carrier of } \\
\text { information }\end{array}$ \\
\hline Information & $\begin{array}{l}\text { Information is } \\
\text { knowledge } \\
\text { through } \\
\text { processed data } \\
\text { or } \\
\text { programming } \\
\text { [19] }\end{array}$ & $\begin{array}{l}\text { For the direct or } \\
\text { indirect } \\
\text { expression of the } \\
\text { way things exist } \\
\text { or their inherent } \\
\text { state, , the } \\
\text { information is } \\
\text { uncertain, and the } \\
\text { data is not. }\end{array}$ & $\begin{array}{l}\text { Information is } \\
\text { a symbol that } \\
\text { has been } \\
\text { interpreted } \\
\text { and is } \\
\text { meaningful } \\
\text { data. }\end{array}$ \\
\hline Knowledge & $\begin{array}{l}\text { It's a result of } \\
\text { knowledge. }{ }^{[20]}\end{array}$ & $\begin{array}{l}\text { Answer to a } \\
\text { question under } \\
\text { specific } \\
\text { conditions }^{[21]}\end{array}$ & $\begin{array}{l}\text { the correct } \\
\text { information }\end{array}$ \\
\hline
\end{tabular}

At the same time, there are hierarchical relations among symbol quality, data quality and information quality. Firstly, there is no definition of symbol quality at present. This paper argues that symbol quality is the accuracy of data use process and belongs to the category of data quantity. Secondly, 
Richard y. Wang et al. ${ }^{[17]}$ believe that data quality is determined by a series of parameters from data consistency, accuracy to correlation. Strong et al. ${ }^{[22]}$ believe that data quality means "data is suitable for use". Fan Wen-fei et al ${ }^{[23]}$ believe that data quality management is the five core issues, namely data consistency, data repeatability, data accuracy, data timeliness and information integrity; Su Qiang ${ }^{[24]}$ believes that data quality is the basis of information quality. Data quality belongs to the category of information quantity. Thirdly, for the difference between information quality and data quality, Strong, Fan Wen-fei, Stuart E. Madnick, and Richard Wang believe that there is no clear boundary between information quality and data quality. Scholar Su Qiang ${ }^{[23]}$ believes that there is an inclusive relationships between information quality and data quality. Chinese scholar Song Li-rong ${ }^{[25]}$ believes that there is a difference between data quality and information quality, and highquality data is not equal to high-quality information. This paper holds that there is a subordinate relationship between information quality and data quality, and that the level of data quality determines the level of information quality. The views of various types are shown in Table III.

TABLE III. VARIOUS VIEWS ON DATA QUALITY, INFORMATION QUALITY, AND KNOWLEDGE QUALITY

\begin{tabular}{|c|c|c|c|}
\hline & $\begin{array}{l}\text { Data } \\
\text { quality }\end{array}$ & $\begin{array}{c}\text { information } \\
\text { quality }\end{array}$ & $\begin{array}{c}\text { knowledge } \\
\text { quality }\end{array}$ \\
\hline Definition 1 & $\begin{array}{l}\text { The extent to } \\
\text { which the data } \\
\text { is suitable for } \\
\text { use }^{[17]}\end{array}$ & $\begin{array}{l}\text { Degree of } \\
\text { satisfaction with } \\
\text { the use of } \\
\text { information } \\
\text { users }^{[28]}\end{array}$ & $\begin{array}{l}\text { In the context of } \\
\text { knowledge } \\
\text { market, } \\
\text { knowledge quality } \\
\text { is the degree to } \\
\text { which knowledge } \\
\text { characteristics } \\
\text { perceived by } \\
\text { knowledge } \\
\text { evaluators meet } \\
\text { expectations }\end{array}$ \\
\hline Definition 2 & $\begin{array}{l}\text { The degree to } \\
\text { meet specific } \\
\text { user } \\
\text { expectations }{ }^{[2} \\
6]\end{array}$ & $\begin{array}{l}\text { Information } \\
\text { should conform to } \\
\text { the specification } \\
\text { [21] }\end{array}$ & $\begin{array}{l}\text { The degree to } \\
\text { which knowledge } \\
\text { conforms to } \\
\text { objective logic }\end{array}$ \\
\hline Definition 3 & $\begin{array}{l}\text { It is } \\
\text { determined by } \\
\text { a series of } \\
\text { parameters } \\
\text { from the } \\
\text { consistency, } \\
\text { accuracy and } \\
\text { relevance of } \\
\text { the data }^{[27]} \text {. }\end{array}$ & $\begin{array}{l}\text { Information } \\
\text { quality = quality } \\
\text { of information } \\
\text { content + quality } \\
\text { of information } \\
\text { collection + } \\
\text { quality of } \\
\text { information } \\
\text { expression + } \\
\text { quality of } \\
\text { information } \\
\text { utility }{ }^{[29]}\end{array}$ & $\begin{array}{l}\text { The extent to } \\
\text { which } \\
\text { requirements are } \\
\text { met in terms of } \\
\text { improving } \\
\text { productivity, } \\
\text { influencing social } \\
\text { life, saving trial } \\
\text { and error costs, } \\
\text { and adding value } \\
\text { to knowledge }\end{array}$ \\
\hline Relationship & $\begin{array}{l}\text { Data quality is } \\
\text { the basis of } \\
\text { information } \\
\text { quality }\end{array}$ & $\begin{array}{l}\text { Data quality exists } \\
\text { in information } \\
\text { quality }\end{array}$ & \\
\hline
\end{tabular}

Similarly, information quality also belongs to the category of knowledge quantity. Therefore, the total information quality management believes that there is a hierarchical relationship between symbol quality, data quality and information quality. The hierarchical relationship mode is shown in Figure 2.

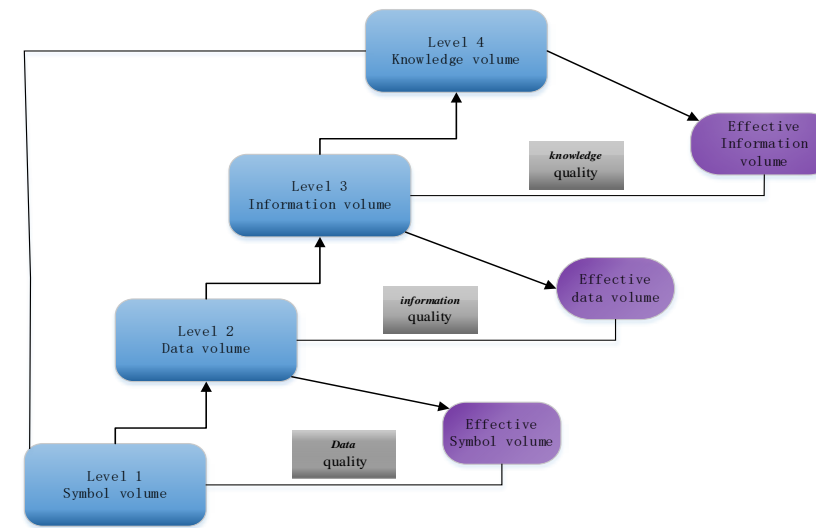

Fig. 2. Comprehensive information quality management hierarchy

The data quality, information quality and knowledge quality of total information quality management can be optimized for the problems of few data, poor information and broken experience under mass customization. And through the research of comprehensive information quality management, taking information quality as the core, the whole process and multi-level management of information quality, reducing information loss and improving information accuracy, thereby improving the satisfaction of information users.

\section{THE RECURRENCE FORMULA}

\section{A. Date quality equation}

Suppose D: $\left\{d_{1}, d_{2}, d_{3} \ldots d_{n}\right\}$ is the set of data events D, $d_{1}^{\prime}, d^{\prime}{ }_{2}, d^{\prime}{ }_{3} . . d^{\prime}{ }_{n}$ is the symbol unit $d$, and $D^{\prime} \in\left\{d^{\prime}{ }_{1}, d^{\prime}{ }_{2}, d^{\prime}{ }_{3 . . .} d_{n,}^{\prime}\right\}$ is the valid symbol event in the $D$ event, D' $\in \mathrm{D}$, then the data quality DQ is shown in Equation (1).

$$
D Q=\sum_{i=1}^{n} \frac{D^{\prime}\left(\mathrm{d}_{i}^{\prime}\right)}{D\left(d_{i}\right)}, \quad i=1,2, \ldots . . n
$$

\section{B. Information quality equation}

Suppose $I:\left\{i_{1}, i_{2}, i_{3} \ldots i_{n}\right\}$ is the set of data events $I$, $i^{\prime}{ }_{1}, i^{\prime}{ }_{2}, i^{\prime}{ }_{3} \ldots i^{\prime}{ }_{n}$ is the symbol unit $\mathrm{I}$, and $I^{\prime} \in\left\{i^{\prime}{ }_{1}, i^{\prime}{ }_{2}, i^{\prime}{ }^{\prime} \ldots i^{\prime}{ }_{n}\right\}$ is the valid symbol event in the I event, $I^{\prime} \in I$, then the data quality IQ is shown in Equation (2).

$$
I Q=\sum_{i=1}^{n} \frac{I^{\prime}\left(i^{\prime}{ }_{i}\right)}{I\left(i_{i}\right)}, \quad i=1,2, \ldots . . n
$$

\section{Knowledge quality equation}

Suppose $K:\left\{\mathrm{k}_{1}, \mathrm{k}_{2}, \mathrm{k}_{3} . . \mathrm{k}_{\mathrm{n}}\right\}$ is the set of data events $\mathrm{K}$, $k^{\prime}{ }_{1}, k^{\prime}{ }_{2}, \ldots k_{n}^{\prime}$ is the symbol unit $\mathrm{k}$, and $K^{\prime} \in\left\{k_{1}^{\prime}, k^{\prime}{ }_{2}, k^{\prime}{ }_{3} . . . k_{n}^{\prime}\right\}$ is the valid symbol event in the $K$ event, $K^{\prime} \in K$, then the data quality $K Q$ is shown in Equation (3).

$$
K Q=\sum_{i=1}^{n} \frac{K^{\prime}\left(k_{i}^{\prime}\right)}{K\left(k_{i}\right)}, \quad i=1,2, \ldots . . n
$$




\section{SUMMARY}

Firstly, this paper summarizes the problems existing in mass customization production, summarizes and overview of information quality management, puts forward the concept and basic theory of total information quality management, and lists recursive formulas. In the process of information quality management, domestic and foreign scholars have already had a wealth of views, but the applicability of comprehensive information quality management and the reliability of recursive equations need further research.

\section{ACKNOWLEDGMENT}

This work was supported by National Natural Science Foundation of China (Grant No.71671089, 71171110).

\section{REFERENCES}

[1] Dong Lan-juan, Fan Shu-hai, Huang Ting-hua, Duan Sai-sai, Shao Jian-feng. Overview of Mass Customization Multivariate Quality Control [J]. Modern Manufacturing Engineering, 2013,(12):125-128.

[2] Fan Shu-hai, Xiao Tian-yuan, Hao Meng. Study on Quality Assurance under Mass Customization [J]. Aviation Precision Manufacturing Technology, 2002, 38(6):1-3.

[3] Jiao J X,Tseng M M, Duffy V G, Lin F. Product family modeling for mass customizat-ion[J]. Computers industry Engineering, 1998,35(3-4) : 495-498

[4] Hart C W, Taylor J R. Value creation through mass customization: Achieving competitive advantage through mass customization [D]. Michigan: University of Michigan Business School Seminar, 1996

[5] Shao Xiao-feng, Huang Pei-qing, Ji Jian-hua. Study on Mass Customization Production Mode [J]. Industrial Engineering and Management, 2001,(2):13-14

[6] Zhang Ping,Fu Xiao-hua. Study on Mass Customization Production and Its Implementation Mechanism [J]. Machinery Manufacturing, 2003,4:49-51

[7] Zhan Yong. Summary and practical application of mass customization production mode theory [J]. Business Times, 2012, (25): 73-74.

[8] Joseph Pine II, Bart Victor, and Andrew C. Boynton. Making Mass Customization Work : Harvard Business Review, 1993.

[9] Wang Ke-jie. The third essence of the quality management master theory [J]. Chinese and foreign management, 1997, (3): 50-51

[10] Zhi Jia. The right culture of quality management [J]. Quality Exploration, 2012, (7): 35-37

[11] (US) S. Thomas Foster. Quality Management: Integrated Approach (Second Edition) [M]. He Wei (Translation). Beijing: China Renmin University Press, 2005: 53-54

[12] Xu Xiao-hui. Customer-defined quality-seeing quality improvement through customer's eyes[J]. Reissue technology, 2014(2):23-27
[13] Song Li-rong. Research on Agricultural Science and Technology Information Quality Management Based on Network Sharing [D]. Beijing: Chinese Academy of Agricultural Sciences, 2008:1-2

[14] (US) Terrence Hawkes. Structuralism and Semiotics [M]. Yan Tiepeng Translation. Shanghai: Shanghai Translation Publishing House, 1987.

[15] Zhang Shao-ying. Analysis of Symbolic Meaning [D]. Nanjing: Nanjing Normal University, 2014: 7.

[16] Zhao Yi-heng. Redefining Symbols and Semiotics [J]. International Journalism, 2013, 6-7.

[17] (United States) Richard Y. Wang and other information quality [M]. Cao Jianjun, Yan Xingchun, Xu Yongping translation. Beijing: National Defense Industry Press, 2013.3

[18] Human Machines and Cognitive Labs. What is data? What is information? [EB/OL].2016.http://mt.sohu.com/20160810/n463447116.shtml.

[19] Deng Hong, Xue Hui-feng. On the Classification Definition of Information Concepts [J]. Journal of Xidian University, 2002, 12(1): 84-85.

[20] Wu Zhen-hua.A New Exploration of the Definition and Relationship of Knowledge and Information [J]. Theory Exploration, 2003,(10):4415.

[21] ALAVI M, LEIDER D E. Review: Knowledge Management and Knowledge Management Systems: Conceptual Foundations and Research issues [J]. MIS quarterly, 2001,25(1): 107 - 136

[22] Strong D M, Lee Y W, Wang R Y. Data quality in context [J]. Communications of the ACM, 1997,40(5): 103-110.

[23] (UK) Fan Wen-fei, (UK) Floris Giltz. Data Quality Management Foundation [M]. Liu Ruihong, Jia Xibei (translation). Beijing: National Defense Industry Press, 2016.1

[24] Su Qiang, Liang Bing. Information Quality and Its Evaluation Index [J]. Computer Systems, 2000, (7): 63-65.

[25] Song Li-rong, Li Si-jing. The Development from Data Quality to Information Quality [J]. Information Science,2010,(2):183-185

[26] Kahn B K, Strong D M. Product and Service Performance Model for Information Quality: An Update [J].IQ, 1998.

[27] Zhou Dong. Successful guarantee of data quality application system [J]. China Information Industry 2006, (12): 39-40.

[28] Gao Zhi-yong, Gao Jian-min,Chen Fu-min.Research on Information Quality in Digital Manufacturing[J]. Computer Integrated Manufacturing Systems, 2005, 11(7):981-985.

[29] Cao Rui-chang, Wu Jian-ming. Information Quality and Its Evaluation Index System [J]. Information Research, 2002, 84 (4):6-8.

[30] Zhou Bo, Zhang Fang. A knowledge quality evaluation model for knowledge market situation [J]. Library and Information Model, 2013, (10):1535-1538.

[31] Liao Yan-ling, Chen Yu-hua,Xu Tian-wei. Evaluation index system of scientific research achievements based on knowledge quality measurement [J]. Science \& Technology Progress and Policy, 2010, (14):130-132. 